DOI: 10.15393/j9.art.2012.354

Ирина Святославовна Андрианова кандидат филологических наук, заведуюшая Web-лабораторией филологического факультета, Петрозаводский государственный университет

(Петрозаводск, Российская Федераиия) yarysheva@yandex.ru

\title{
КОНЦЕПЦИЯ ЖАНРА ДНЕВНИКА А. Г. ДОСТОЕВСКОЙ
}

Аннотация: Стенографический дневник жены писателя Ф. М. Достоевского представляет собой записи о семейной и творческой жизни супругов в Европе в 1867-1868 гг. Исследователи творчества Достоевского обращаются к дневнику его супруги только как к источнику биографических сведений, не уделяя внимания его художественным особенностям. В данной статье поставлена актуальная и новая задача - сделать анализ стенографического дневника А. Г. Достоевской как литературного произведения, исследовать его творческую историю и историю публикации, жанровое содержание, структуру, пространственно-временную организацию, образ автора и образ главного героя. Стенографический дневник жены писателя стал первым в России образцом этого жанра, его главная особенность - предельная откровенность, т. к. он не предполагался для печати. Значительный интерес представляют выводы автора статьи о том, что А. Г. Достоевская стала создателем новой разновидности жанра личного дневника в русской литературе - личного стенографического дневника.

Ключевые слова: русская литература XIX века, Ф. М. Достоевский, А. Г. Достоевская, мемуарная литература, личный стенографический семейно-бытовой дневник

$\Lambda$

ичный дневник как литературный жанр начал осмысливаться только во второй половине ХХ столетия. До этого времени преобладал историографический и фактографический подход: дневниковые тексты воспринимались как вспомогательные, служебные материалы для научных исследований в области литературы, истории и других общественных наук. Начиная с 1950-х гг. исследователи заговорили о необходимости изучать дневники с художественной точки зрения [24]; [35], о важности автономного исследования творческих дневников писателей [31], о «поэтике дневникового текста» [8], обсуждаются проблемы жанровой формы, структуры дневникового текста, его соотношения с художественной прозой и документалистикой. Так, Л. Я. Гинзбург считала дневник промежуточным жанром [6], А. Г. Тартаковский рассматривал дневниковую литературу как жанр мемуарной прозы [32]; [33], В. Д. Оскоцкий заявлял о мемориальном характере дневника [28], Б. Хазанов определяет дневник как «литературный жанр, который представляет собой протест против литературы с ее жанрами и приемами» [34]; Л. М. Гапека и А. В. Лашкевич относят дневник к суб-литературе [5], а М. Ю. Михеев называет его «пред-текстом», «перво-текстом», «обыденной литературой» [25]; [26]. Комплексное исследование дневникового жанра 
как литературного явления представил О. Г. Егоров [14]; [15]; [16]. Он рассмотрел метод, стиль, типологию, жанровое содержание, систему образов в дневниках разных авторов, в том числе и не литераторов. Исследователь подчеркнул универсальность дневникового жанра:

«Дневник служит показателем литературной образованности, но последнее качество не является определяющим при создании дневника» $[16,15]$.

Признанием литературного значения дневников стала их публикация в серии «Литературные памятники», книги которой «рассчитаны на читателя, стремящегося к глубокому и всестороннему пониманию выдающихся произведений разных эпох и народов мира»1. В числе их в 1993 году вышел дневник Анны Григорьевны Достоевской.

Ни одна крупная работа о писателе Достоевском не обходится без обращения к дневнику его жены как источнику биографических сведений. Между тем не существует исследований, в которых бы рассматривались художественные особенности этого произведения. В данной статье поставлена актуальная и новая задача сделать анализ концепции жанра стенографического дневника А. Г. Достоевской, исследовать его «литературность», творческую историю и историю публикации, жанровое содержание, структуру, пространственно-временную организацию, образ автора и образ главного героя.

Дневник Анны Григорьевны представляет собой записи о семейной и творческой жизни супругов Достоевских в Европе в 1867-1868 гг., куда они отправились через два месяца после свадьбы с целью наладить семейные отношения, избежать кредиторов и создать благоприятные условия для написания романа в журнал «Русский вестник».

В мемуарах жены писателя, создаваемых в 1911-1916 гг., указано несколько причин, по которым возник дневник. Это, кроме ежедневной практики в стенографии, необходимость фиксировать для памяти новые впечатления от заграничной жизни, желание лучше узнать мужа записыванием его мыслей и замечаний $[9,156]$.

Была и психологическая причина ведения дневника, характерная для юных авторов и обусловленная возрастным процессом самоосуществления личности, или индивидуации (термин К. Юнга). Дневник для молодой жены Достоевского стал словесной формой выражения душевной жизни, хранителем событий нового этапа психологического развития, вызванного освобождением от родительского влияния и первыми сложностями супружеской жизни с выдающимся писателем современности:

«...за границей я была вполне одинока, мне не с кем было разделить моих наблюдений, а иногда возникавших во мне сомнений, и дневник был другом, которому я поверяла все мои мысли, надежды и опасения» $[9,156]$. 
Более того, по наблюдению исследователей истории жанра, для женщин ведение дневника было насущной потребностью. Они «находили в этой повседневной практике способ самореализации, позволявший им в то же время оставаться в предписанных „второму полу" домашних рамках» [4].

В черновых набросках воспоминаний и в интервью журналисту А. А. Измайлову $[21,190]$ Анна Григорьевна указывает еще одну причину ведения подробных записей во время заграничного путешествия. Двадцатилетняя девушка дает обещание матери по приезду поделиться впечатлениями от жизни в Европе:

«...чтобы многаго не забыть объщала завести записную книжку, въ которую и вписывать день за днемъ все что со мною будетъ случаться. Слово мое не отстало отъ дъла: я тутъ же на станціи купила записную книжку и съ сльдующаго дня принялась записывать стенографически все что меня интересовало и занимало»².

Как заметил О. Г. Егоров, подобная причина является самой типичной из тех, по которым возникали юношеские дневники XIX века. Родители часто рекомендовали процедуру ведения дневника, т. к., по их понятиям, он «должен служить средством умственного и нравственного воспитания юноши или девушки. <...> Молодой человек пишет хронику своей внутренней жизни и социального поведения и на ее основе корректирует свои мысли и поступки» $[16,22]$.

Таким образом, непосредственным адресатом дневника Достоевской является она сама, точнее ee alter ego, надсубъект, „высшая инстанция ответного понимания" [1, 149]. Дневник жены писателя - это ее предельно откровенный разговор с самой собою, монолог, обращенный к себе, исповедь перед Богом:

«Наконец, я встала и помолилась Богу, потому что я надеюсь, что он даст мне силы перенести все это. Господи, да такие ли бывают несчастия, это ли можно назвать несчастием; зачем же быть такой малодушной?» $[11,149]$.

В роли косвенного адресата дневника выступает мать Анны Григорьевны - потенциальный читатель-слушатель, которого планируется ознакомить с содержанием записей.

Безусловно, данный документ 20-летней девушки не задумывался изначально как литературное произведение, рассчитанное на публикацию и гласность. Его интимный, засекреченный от окружающих характер подтверждает форма ведения - стенографические записи. О содержании дневника не было известно даже Ф. М. Достоевскому. «Дорого бы я дал, чтоб узнать, Анечка, что ты такое пишешь своими крючочками», - признавался супруг $[9,156]$.

Стенографический дневник А. Г. Достоевской хранится в Научно-исследовательском отделе рукописей Российской государственной библиотеки (ОР РГБ) (ф. 93, разд. III, карт. 5, ед. хр. 15a, 156) и состоит из записных книжек, предназначенных, судя по типографским 
записям «debet-credit» в верхней части листов, для бухгалтерских подсчетов. Листы в записных книжках Достоевская карандашом разметила в линейку. Это удобно для скоростного письма, т. к. рука начинающего стенографа должна привыкнуть выписывать в одну линию знаки разной высоты - так называемые мерные, полумерные, малые и длинные. Различение высоты знака особенно важно при расшифровке стенограммы.

Знание стенографии давало возможность молодой супруге писателя запечатлевать на бумаге самые мимолетные чувства, настроения, мысли, переживания, а также позволяло быть предельно откровенной в своих записях. Эти особенности дневника А. Г. Достоевской отличают его от других образцов жанра, созданных в XVIII-XIX столетиях. Принимая во внимание установку на откровенность, их авторы, тем не менее, предвидели возможность прочтения их записей другими лицами и придерживались другой установки - «нежелания говорить „всё” (по выражению К. Вьолле и Е. П. Гречаной). Подтверждая это, исследовательницы приводят в пример дневник Н. В. Шаховской за 1841-1842 гг., автор которого подчеркивает «внешний» характер своего текста:

«...я никогда не решусь доверить бумаге мои самые тайные мысли» $[4,32]$.

Об уникальности жанра дневника писала А. Зализняк:

«...дневник пишется как будто исключительно для себя и поэтому без рисов$\kappa и$, но одновременно именно это и оказывается интересно другим - тем, кем он, возможно, будет прочитан» [20].

В этом смысле ключевой для жанра дневника является фигура косвенного адресата - возможного читателя. К. Кобрин поставил важнейший вопрос:

«...все ли авторы дневников надеются, что их прочтут после смерти? Ответить сложно; в любом случае, многие дневники мы прочли, и ни один из них, кажется, не был предназначен для собственного употребления <... Дело в том, что бессознательно, если он хочет потом сам читать собственный дневник, то не может не представить на своем месте другого, хотя бы на мгновение» [22, 291].

Известно, что немецкий ученый-зоолог А. Брем создавал свою знаменитую научно-популярную работу «Жизнь животных», пользуясь материалами стенографического дневника, который он вел в 60-е гг. XIX века. Стенографический дневник А. Г. Достоевской стал первым в России образцом этого жанра, причем, в отличие от дневника А. Брема, более откровенным, так как не предполагался для печати. (Заметим попутно, что факт авторского «криптографирования текста» является для исследователя М. Ю. Михеева основанием отнесения дневника А. Г. Достоевской, вместе с дневником Леонардо да Винчи, написанным специально разработанным им шрифтом, к пред-литературной прозе, или «обыденной литературе» [26].) 
Литературная судьба стенографического дневника А. Г. Достоевской (история текста и публикации) складывалась своеобразно. На сегодняшний день существуют три отдельных издания текста дневника, вышедшие с различными принципами публикации под редакцией Н. Ф. Бельчикова [10], С. В. Житомирской [11], С. В. Белова [2]. Это связано с особенностями жанра и структуры стенографического дневника А. Г. Достоевской.

В конце жизни вдова писателя сама расшифровала часть дневника:

«Перечитывая записные книжки мужа и свои собственные, я находила в них такие интересные подробности, что невольно хотелось записать их уже не стенографически, как они были у меня записаны, а общепонятным языком, тем более что я была уверена, что моими записями заинтересуются мои дети, внуки, а может быть, и некоторые поклонники таланта моего незабвенного мужа» $[9,35]$.

Текст ее расшифровки был издан в 1923 г. Н. Ф. Бельчиковым. Исследователь в предисловии высказал предположение о том, что опубликованный им текст не исчерпывает всего дневника в целом. А. С. Долинин вскоре после издания «Дневника А. Г. Достоевской» указал на существование стенографических книжек в оставшемся после супруги писателя архиве и выказал надежду на то, что «быть может, удастся когда-нибудь расшифровать дальнейшие стенографические записи» $[7,250]$.

В 60 -е гг. XX века исследованием структуры дневника жены писателя занимались архивист С. В. Житомирская и стенографистка Ц. М. Пошеманская. Они установили, что из четырех стенографических книжек-тетрадей, составлявших дневник, до нашего времени не сохранилось последней, четвертой. Первая книжка существует в двух вариантах: стенографическом и расшифрованном через 27 лет Достоевской; вторая - лишь в расшифрованном женой писателя виде (спустя 30 лет). Анна Григорьевна начала расшифровку дневника в 1894 г., «несколько раз прерывала работу, а зимой 1911-12 г. совсем ее оставила» $[17,396]$. Вероятно, первоначально она имела намерение его опубликовать или сохранить для потомства в таком виде, который отвечал бы ее требованиям. Во всяком случае, она не просто расшифровывала, но и редактировала, устраняла многочисленные подробности, касающиеся интимных сторон жизни ее семьи, перерабатывала живые и необдуманные записи стенографического дневника, зачастую давая свободу домыслу и вымыслу, в том числе и в целях достижения художественной выразительности. В ряде случаев эти переработки расшифрованного текста непосредственно легли в основу соответствующих глав ее мемуаров. Наиболее важные смысловые изменения касались личности Достоевского, его идейных позиций, его отношения к известным современникам, особенностей его характера и поведения [17]; [19]. 
Жена писателя остановилась в расшифровке дневника на тексте от 12 (24) августа 1867 года, относящемся к пребыванию их семьи в Базеле, и оставила завещательное распоряжение:

«Въ числь оставшихся посль меня тетрадей найдутся двъ-три/-четыре/ ${ }^{3}$, исписанныя ${ }^{4}$ стенографическими знаками. Въ этихъ тетрадяхъ заключается Дневникъ, который я вела съ выъзда нашего за границу, /в 1867 г./5 въ теченіи полутора года 6 . Часть Дневника была мною переписана ${ }^{7}$ года два тому назадъ... Остальныя тетради я $\boldsymbol{n p o w y ~ у н и ч т о ж и т ь . . . ~ м н ъ ~ в о в с е ~ б ы ~} \boldsymbol{H E}$ хотьлось, чтобъ чужіе люди проникали въ нашу съ $\Theta<$ едоромъ $>\mathrm{M}<$ ихайловичемъ > семейную интимную жизнь».

В конце 1950-х — начале 1970-х гг., вопреки завещанию, проникновение в тайны семейной жизни произошло, когда первую и третью тетради расшифровала стенографистка Ц. М. Пошеманская. Причины этого нарушения авторского запрета исследователь С. В. Белов, автор книг и статей, посвященных деятельности Достоевской, объясняет так:

«В интервью различным корреспондентам Анна Григорьевна не настаивает на уничтожении стенографических тетрадей 1867 г.; да она и сама этого не сделала, зная, что ни у одного писателя мира нет такого соответствия между личной жизнью и произведениями» $[2,24]$.

Ц. М. Пошеманская, в поисках ключа к стенографическим записям Достоевской, проделала настоящую исследовательскую работу, получившую в статье газеты «Известия» (от 03.06.1959) заслуженное название «Подвиг стенографистки». Вначале она изучила учебник стенографии, изданный учителем Достоевской П. М. Ольхиным [27]. Это было необходимо даже для опытной стенографистки, поскольку принятые в настоящее время способы стенографирования довольно далеки от тех, какими пользовались в XIX веке. Но, учитывая то, что Анна Григорьевна часто применяла свои сокращения и знаки, для расшифровки ее стенограмм оказалось недостаточно только изучить учебник. Пошеманской пришлось сравнить расшифрованную (и к тому времени опубликованную) часть дневника со стенографическими книжками и составить список личных сокращений Достоевской. В итоге она выяснила, что одна из этих книжек соответствует первой из двух расшифрованных Анной Григорьевной книжек дневника. Найдя ключ к стенографической системе жены писателя, Пошеманская расшифровала и первую, и третью книжку - неизвестную до того времени.

Третья книжка в расшифровке Ц. М. Пошеманской под редакцией С. В. Житомирской была впервые опубликована в 1973 г. в 86-м томе издания «Литературное наследство: Ф. М. Достоевский. Новые материалы и исследования». Полный текст дневника Достоевской получилось выпустить в России лишь спустя 20 с лишним лет после расшифровки (до этого времени С. В. Житомирская 
и Ц. М. Пошеманская опубликовали его в Польше, Германии и Японии $[18,475])$. В один и тот же год (1993) в Санкт-Петербурге и Москве вышли два издания полных текстов дневника жены писателя. В составе первого из них, подготовленного С. В. Беловым, - две книжки, расшифрованные самой А. Г. Достоевской и третья книжка в расшифровке Ц. М. Пошеманской. С. В. Житомирская подготовила текст дневника для серии «Литературные памятники», эта публикация включала первую и третью книжку в расшифровке Ц. М. Пошеманской, а вторую - А. Г. Достоевской.

Структурообразующим элементом дневника являются пространственные и временные рамки. Дневник XIX века выработал три классические разновидности пространственно-временной организации текста, которые были сформулированы О. Г. Егоровым как локальный, континуальный и психологический хронотопы.

«В рамках первой формы субъект повествования является участником или очевидцем описываемых событий. Во второй в сферу повествования включаются события, свидетелем которых автор не мог быть в силу их пространственной удаленности. В третьей форме событиями являются факты душевной жизни повествователя, непосредственно не связанные с миром физических или общественных явлений» $[14,6]$.

Н. Ф. Бельчиков, опубликовав в 1923 г. часть дневника, расшифрованную самой Достоевской, не зная содержания оставшихся в стенографированном виде книжек, писал о том, что дневник имеет локальный хронотоп:

«Couleur locale Дневника - заграница, а не Россия. А. Г. Достоевская начала дневник по выезде из России и вела его около года или более, пока жила за границей. События же с момента въезда в Россию в 1871 г. она занесла в свои „Воспоминания"» $[3, \mathrm{XII}]$.

Исследователь критично относился к высказыванию Л. Ф. Достоевской о дневнике матери:

«Этот наивный дневник ее юности она сохранила, так что имела возможность позже восстановить время их помолвки и медового месяца почти день за днем. Эти интересные воспоминания предполагалось издать, но вспыхнула эта ужасная война» $[12,53]$.

Он полагал, что дочь перепутала содержание дневника с воспоминаниями, поскольку по имеющимся у него материалам речь о помолвке и медовом месяце Достоевских шла в воспоминаниях и совершенно отсутствовала в дневнике.

С появлением в печати в 1993 г. части дневника, расшифрованной Ц. М. Пошеманской, определилось, что в его основании лежит оригинальная, смешанная (дуальная) форма хронотопа. О. Г. Егоров отмечает, что группа дневников с дуальной системой хронотопа невелика (в качестве примеров он приводит дневники А. В. Никитенко 
и С. А. Толстой) и «заметно выделяется на фоне классических образцов жанра» $[16,80]$. Впервые в дневниковой записи от 30 августа (11 сентября) 1867 года (в день своего рождения) А. Г. Достоевская вводит воспоминания о том, какие примечательные события происходили с ней в этот день в прошлом — в 1866, 1865 и 1861 гг. В тексте дневника есть примечание, объясняющее их появление в тексте:

«Желая себя чем-нибудь развлечь от грустных мыслей, я записала тут мои воспоминания первой юности, именно от 1860 г. ${ }^{9}$, и поездку мою на дачу к Сниткиным в 1866 году. <...> Если будет время, перепишу отдельно» $[11,186]$.

Обозначив записи пережитого «воспоминаниями» и имея намерение переписать их отдельно от дневникового текста, Анна Григорьевна выступает как человек, осведомленный в теоретических вопросах историко-литературного порядка. С 6 октября в дневниковых записях Достоевской за 1867 год параллельно появляются воспоминания о событиях, происходивших с ней год назад в тот же день: знакомстве с писателем, работе с ним над романом «Игрок», первом времени жениховства. Локальная форма хронотопа, превалировавшая ранее, теперь окончательно вытесняется смешанной (дуальной), когда время идет в двух параллельных измерениях, обладающих самостоятельной ценностью, - в настоящем и прошлом. Осознание своего взросления и безрадостное настоящее, обусловленное тяжелым материальным положением Достоевских («у меня на душе тоска и... мне жизнь не очень-то сладка... Право, я только и желаю, хотя бы день сегодня прошел, думаю я, вот еще бы день, да только поскорей, пока какие-нибудь денежки придут, и мы не станем так сильно нуждаться» $[11,315])$ рождает воспоминания о счастливом прошлом:

«Вообще это было очень счастливое время, как я припоминаю, и дай Бог всякому быть таким счастливым, как я была в это время» $[11,372]$.

Эту мысль Анны Григорьевны вести дневник за нынешний и прошлый год писатель П. П. Косенко называет неосознанной литературной выдумкой:

«Можно было бы ведь записать прошлогодние воспоминания отдельно и связно; нет, что-то заставляет ее распределять материал строго по датам... и получается весьма выразительный литературно-документальный параллельный монтаж» $[23,65]$.

Об оригинальном характере дневника А. Г. Достоевской свидетельствуют художественные произведения, включенные в его структуру. На последних страницах дневника А. Г. Достоевской записаны (частично стенографически) шесть поэтических шуток, сочиненных вместе с мужем во время пребывания в Европе. Это назидательно-дидактическая басня «Дым и Комок», комическая пьеса 
«Абракадабра», стихотворные импровизации на бытовые темы «Два годы мы бедно живем...», «Есть ли у тебя, брат, совесть...», «Вся в слезах негодованья...», «Я просил жену о мыле...». Это была «своего рода литературная школа, в которой знаменитый писатель исподволь, в традициях совмещения приятного с полезным, формировал вкусы своей молодой жены» [29, 413].

С предназначением дневника А. Г. Достоевской тесно связано его жанровое содержание. Многие дневники XIX в. являются путевыми: «достойным описания поначалу считалось путешествие в дальние страны» [4, 21]. Достоевский считал, что и его жена ведет путевой дневник: «Анна Григорьевна оказалась чрезвычайной путешественницей: Куда ни пріьдетъ, тотчасъ-же все осматриваеть и описываетъ, исписала своими знаками множество маленькихъ книжекъ и тетрадокъ...», - писал он племяннице С. А. Ивановой 29 сентября (11 октября) 1867 г. ${ }^{10}$ Однако, несмотря на то, что дневник Достоевской велся во время заграничного путешествия, задумывался как путевой и начинается с момента отъезда («Мы выехали из Петербурга в 5 часов в веселый ясный день 14 апреля» $[11,5])$, он не является таковым. Описание европейских достопримечательностей находится в нем на отдаленном плане и встречается преимущественно вначале - до 18 апреля, когда впечатления от архитектуры городов, преобладающие в предыдущих записях, сменяются рассказом о первой ссоре с мужем. Это признает и его автор:

«Сначала я записывала только мои дорожныя впечатльнія и описывала нашу вседневную жизнь. Но мало по малу мнъ захотьлось вписывать все что такъ интересовало и пльняло меня въ моемъ дорогомъ мужъ: его мысли, его разговоры, его мнънія о музыкъ, о литературь и пр. Записывала и наши маленькія распри, мой протестъ противъ нъкоторыхъ его взглядовъ, напр. по поводу женскаго вопроса. Я могла свободно записывать, такъ какъ знала, что никто кромъ меня не прочтетъ мною записаннаго» ${ }^{11}$.

Дневник Достоевской - семейно-бытовой по жанровому содержанию. Характерной особенностью таких дневников является то, что их авторы уравнивают рядовые происшествия с более значительными событиями жизни [16, 148]. В дневнике Достоевской культурный и домашний быт неразделимы. Она подробно и последовательно описывает свой день - с момента пробуждения до приготовления ко сну (запись om 14 (26) мая: «Я встала сегодня довольно рано, чтобы идти на почту, а потом в церковь <...> Я тотчас же легла в постель, боясь поздно проснуться» $[11 ; 53,56])$. В ее дневнике - множество упоминаний о том, сколько стоил найм квартиры, новая шляпка, фунт вишен. Несмотря на молодость, Анна Григорьевна обладала задатками хорошей, расчетливой хозяйки. К примеру, в Баден-Бадене она купила любимый пирожок с орехами и сделала запись в дневнике: 
«...здесь они дороги, именно за пирожок просят 6 Kr., <крейцеров. - И. А.>, около 6 копеек, это довольно дорого: у нас и в самых лучших булочных продают за 5 копеек» $[11,175]$.

Дневник наполнен многочисленными деталями, которые зримо воссоздают семейный быт, - от хозяйственных мелочей до супружеских ссор и примирений:

«...за чаем поссорились с Федей из-за его сочинения. Я хотела прочитать строчку из его „Записок из подполья”, но он на меня закричал и велел просить прощения. <...> Но мы скоро помирились» $[11,61]$.

Как точно заметил О. Г. Егоров, «предметный мир приобретает в дневнике особую значимость в силу неустойчивости <материального. - И. А.> положения Достоевских. Он поглощает значительную часть дня и часто оттесняет на второй план сферу общения и духовной жизни. Бытовизм на какое-то время отождествляется с понятием „образ жизни”. Он является не фоном, а жизненной средой и, следовательно, главным предметом изображения» $[16,150]$.

Сфера общения и духовной жизни Достоевских представлена в дневнике совместным творческим процессом: он - писатель, она - стенографистка и корректор («кончив мою работу, я принялась читать, а Федя сел опять писать. Нынче он пишет и вечером, все составляет план романа. Господи, как я ему от души желаю, чтобы роман вышел очень хороший. Это мое единственное и самое искреннее желание» $[11,298])$. Семейный досуг Достоевских в Европе состоит из совместного сочинительства шуточных стихов, прослушивания музыки (Моцарта, Вагнера, Бетховена, Россини), посещения библиотек, музеев и картинных галерей.

Особое место в дневнике А. Г. Достоевской занимает описание религиозной жизни семьи. Жена писателя по праздничным и воскресным дням обыкновенно ходила в церковь, тогда как Ф. М. Достоевский за границей редко там бывал. В дневнике упоминание о совместном посещении супругами православного храма единично:

«Мы заходили в русскую церковь Никол<ы>, недостроенную, на Большой улице, поклониться Плащанице» $[11,5]$.

Семейный быт Достоевских включал обсуждение религиозных вопросов:

«Потом вечером у нас обыкновенно идут разговоры; так, вчера мы говорили о евангелии, о Христе, говорили очень долго» $[11,275]$.

В дневнике А. Г. Достоевской умело представлены образы автора, образ главного героя, второстепенные персонажи, даны портретные характеристики, выражена авторская оценка. Главным, связующим образом стенографического дневника выступает Ф. М. Достоевский «Федя», «Федичка». В связи с этим дневник Анны Григорьевны представляет собой в некотором роде «записи за великим человеком» [25], 
текст о Достоевском. Таковы также «Дневник» секретаря Екатерины II А. В. Храповицкого, обширные записи за Львом Толстым - его секретарей Н. Н. Гусева, В. Ф. Булгакова, доктора Д. П. Маковицкого, дочерей Татьяны и Александры.

Образ Ф. М. Достоевского, писателя и мужа, - предмет особой заинтересованности автора, он строится путем последовательного прибавления черт характера, жизненных обстоятельств, поступков, с каждым разом раскрываясь полнее, обогащаясь, усложняясь. Рисуя близкого и дорогого человека, Анна Григорьевна создает целостный диалектический образ, в котором сочетаются реальные свойства его характера и отношение к нему жены:

«Я посмеялась этому, но Федя обиделся и начал отворачиваться от меня, как маленький ребенок, и уверял, что он оскорблен» (от 18 (30) мая) [11, 60]; «Он объявил, что не сердится, но что обдумал и решил, как ему действовать, что надо между нами положить границы. Я ему отвечала смело, что пусть он там как ему угодно перекладывает границы, но что я нисколько этому подчиняться не намерена, и поэтому все эти перекладки будут тотчас поломаны и все пойдет по-старому» (от 22 мая (3 июня)) [11, 67]; «Как я подумаю, как изменился его характер - это

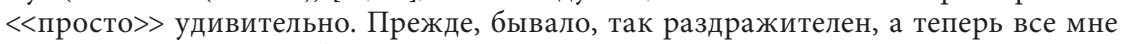
сходит с рук. Прежде, бывало, он так страшно кричит, что я просто иногда страшилась за свою будущую жизнь. Если бы он и при мне не изменился, то это было бы просто мукой» (от 3 (15) июня) $[11,85]$; «Проснулись мы в очень хорошем расположении духа, так что Федя даже смеялся, лежа в постели, и дразнил меня, по обыкновению. Милый Федя, какой он славный и как меня любит» (от 25 июля (6 августа) [11, 185].

Нервный, вспыльчивый, брюзжащий, непредсказуемый в своих поступках, неприспособленный в быту, талантливый, вдохновенный, заботливый, любящий - таким предстает писатель в дневнике его жены, его образ проходит эволюцию вместе с тем, как он становится ближе и понятнее ей.

Вместе с главным героем дневника «Федичкой» выводится и образ автора, присутствующий в каждой записи. Он раскрывается и через семейные, социальные отношения, и через строй эмоций и чувств, и через самохарактеристики:

«Меня теперь очень нетрудно вывести из себя. Я не знаю, в каком это я состоянии, но чтобы вывести меня из терпения, нужно очень немного. Я сейчас же волнуюсь и не знаю, что говорю и что делаю» $[11,161]$; «Я сержусь на себя, зачем у меня такие дурные мысли против моего дорогого, милого, хорошего мужа. Верно, я злая!» [11, 175]; «Я целый день сегодня ужасная шутиха, смеялась, не зная чему, так что даже досада берет» [11, 108].

Не случайно слова «смеяться», «смех», «смешно» чаще других используются автором дневника: с материальными и другими семейными трудностями заграничного периода жизни Достоевской помогает справиться ее чувство юмора, умение посмеяться над собой и проблемами, вызывающее симпатию к ней у читателя. 
Вместо запланированных трех месяцев Достоевские прожили за границей четыре года - с 1867 по 1871. Расшифрованный и изданный дневник жены писателя (в связи с возможным отсутствием последней, четвертой книжки) охватывает период заграничной жизни молодоженов с 14 (26) апреля до 10 (22) декабря 1867 г. Хронологические же рамки его ведения, как установили Ц. М. Пошеманская и С. В. Житомирская, охватывают около года и заканчиваются февралем-мартом 1868 г.

Со временем записи дневника становились все короче. Если в начале путешествия Анна Григорьевна исписывала целые страницы, то в декабре она ограничилась лишь несколькими строчками. Постепенно стенографистка охладела к ведению дневника, а хлопоты, связанные с рождением дочери Сони (22 февраля (5 марта) 1868 г.), и стенографирование нового романа (Достоевский в это время работал над «Идиотом») поглотили все свободное время. В конце концов она прекратила вести дневник.

Процесс записывания чувств и мыслей помог Анне Григорьевне сохранить основные, стержневые качества ее личности (честность, доброту, самостоятельность, трудолюбие и др.), но и успешно преодолеть стадию психологической индивидуации. В Россию вернулась не кроткая, наивная, неуверенная в себе, порой истеричная девушка, а решительная, практичная, духовно развитая, мудрая и понимающая жена. Зафиксированные в дневнике живые, откровенные и часто незрелые суждения молодой женщины, ее рассказы о бытовой и религиозной жизни, духовном общении и работе с великим писателем в 1867 г. подводят намного ближе к истинному, сложному облику Достоевского, создавая эффект присутствия читателя при событиях прошлого.

На сегодняшний день, кроме Ц. М. Пошеманской, никто не смог расшифровать стенограммы жены писателя, подобрать ключ к ее системе скорописи. Но и она не смогла раскрыть все «тайны» дневника А. Г. Достоевской: отдельные слова и записи дневника остались разобранными предположительно, имеют несколько вариантов прочтения или не расшифрованы совсем. Это отражено в постраничных примечаниях изданий (напр., к словам: «Потом видели крест» - примечание: «Может быть: крепость» и т. д.) или редакторских пометах в тексте («Я взобралась на гору и осмотрела <слово не расшифровано> русскую церковь»; «Федя начал выходить из себя, бранил меня за то, что <слово не расшифровано> не знаю дорогу» $[11 ; 5,127,211]$ и т. п.). В ОР РГБ сохранились машинописные листы расшифрованных Ц. М. Пошеманской стенограмм ${ }^{12}$. Они доказывают, с одной стороны, масштабность труда стенографистки, с другой - отражают творческий процесс расшифровки, сомнения 
Пошеманской, из-за которых в расшифровках могут быть неточности, искажения. В качестве примера приведем один случай. Пошеманская изначально не расшифровала слова, следующие за текстом: «Потом он сел писать» - и объяснила причины этого в постраничной сноске машинописного текста: «<слово не разобрано, т. к. сильно сокращено>». Затем все-таки вписала вариант расшифровки: «о бонапартизме», прокомментировав: «Предположительно. Сокращено как „о бон-зме”». Окончательный вариант она вписала позднее, не исключено, что изучив творческую биографию Достоевского, - «О Белинском» $»^{13}$.

В настоящее время предпринимаются новые попытки расшифровать стенографические знаки жены писателя. Так, в 2011 году в ПетрГУ была начата работа над проектом «Автоматизированная система распознавания и дешифровки стенограмм XIX - начала XX в.» [30].

Несмотря на то, что стенографический дневник А. Г. Достоевской не предполагался для печати, он не только обладает литературными достоинствами традиционного личного дневника, но и представляет новую разновидность этого жанра в русской литературе - личный стенограбический дневник.

\section{Примечания}

Работа выполняется при финансовой поддержке Программы стратегического развития ПетрГУ в рамках реализации комплекса мероприятий по развитию научно-исследовательской деятельности.

1 Гаспаров М. Л., Гришунин А. Л., Михайлов А. Д., Птушкина И. Г. Предисловие // Литературные памятники. 1948-1998: Аннотированный каталог. М., 1998. С. 9.

2 Достоевская А. Г. Воспоминания // РГАЛИ. Ф. 212. Оп. 1. Ед. хр. 147. Л. 307307 об.

Слово «четыре» вставлено карандамом позднее.

Первоначальный незачеркнутый вариант: «написанныя».

«въ 1867 г.» вставлено карандашом позднее.

Так в рукописи. Нужно: «льтъ».

Имеется в виду: «расшифрована и переписана».

8 Достоевская А. Г. Записная тетрадь с заголовком: «Объяснения домашних дел и указания, сделанные А. Г. Достоевской на случай ее смерти или тяжкой болезни, в марте 1902 года и в последующие годы» (1902-1911) // РГАЛИ. Ф. 212. Оп. 1. Д. 224. Л. 47.

91860 г. здесь указан очибочно, т. к. в дневнике рассказывается о событиях 18612.

10 ОР РГБ. Ф. 93. Разд. І. Карт. 6. Ед. хр. 17. Л. 1 об. (Ср.: Достоевский Ф. М. Полн. собр. соч.: в 30 т. Л., 1985. Т. 28. Кн. 2. С. 223.)

11 Достоевская А. Г. Воспоминания // РГАЛИ. Ф. 212. Оп. 1. Д. 147. Л. 307 об.308.

12 Ф. 93. Разд. III. Карт. 5. Ед. хр. 15в, 15г.

13 Помеманская Ц. М. Машинопись расшифрованной стенограммы дневника А. Г. Достоевской // ОР РГБ. Ф. 93. Разд. ІІІ. Карт. 5. Ед. хр. 15в. Л. 3. 


\section{Список литературы}

1. Бахтин М. М. Заметки к неосуществленному труду. Проблема текста. Опыт философского анализа // Вопросы литературы. 1976. - № 10. - С. 122-151.

2. Белов С. В. Последняя любовь Ф. М. Достоевского // Последняя любовь Ф. М. Достоевского: А. Г. Достоевская. Дневник 1867 года. - СПб.: Андреев и сыновья, 1993. - С. 5-26.

3. Бельчиков Н. Ф. Предисловие // Дневник А. Г. Достоевской. - М., 1823. C. VI-XVI.

4. Вволле К., Гречаная Е. П. Дневник в России в конце XVIII - первой половине XIX в. как автобиографическое пространство // Известия АН. - 2002. № 3 (61). - C. $18-36$.

5. Гапека Л. М., Лашкевич А. В. Личный дневник как жанр суб-литературы: проблема структуры и функции «diary» в контексте межкультурной коммуникации // Синтез документального и художественного в литературе и искусстве: Сборник статей и материалов Международной научной конференции (3-6 мая 2006). - Казань, 2007. - С. 391-396.

6. Гинзбург Л. Я. О психологической прозе. - М.: Интрада, 1999. - 414 с.

7. Долинин А. С. Достоевский и Суслова // Ф. М. Достоевский: Статьи и материалы / Под ред. А. С. Долинина. - Л.; М.: Мысль, 1924. - С. 153-283.

8. Донченко Н. Ю. Поэтика антиномии в «Дневниках» М. Пришвина: автореф. дис. ...канд. филол. наук. - М., 1999. - 19 с.

9. Достоевская А. Г. Воспоминания. - СПб.: Азбука, 2011. - 480 с.

10. [Достоевская А. Г.] Дневник А. Г. Достоевской. - М.: Новая Москва, 1923. $390 \mathrm{c}$.

11. Достоевская А. Г. Дневник 1867 года. - М.: Наука, 1993. - 452 с.

12. [Достоевская Л. Ф.]. Достоевский в изображении его дочери Л. Достоевской. - М.; Пг.: Госиздат, 1922. - 105 с.

13. Достоевский Ф. М. Полн. собр. соч.: в 30 т. - Л.: Наука, 1972-1990.

14. Егоров О. Г. Дневники русских писателей XIX века: исследование. - М.: Флинта: Наука, 2002. - 287 с.

15. Егоров О. Г. Литературный дневник XIX века: История и теория жанра: дис. ...д-ра филол. наук. - М., 2003. - 360 с.

16. Егоров О. Г. Русский литературный дневник XIX века. История и теория жанра: исследование. - М.: Флинта: Наука, 2003. - 279 с.

17. Житомирская С. В. Дневник А. Г. Достоевской как историко-литературный источник // Достоевская А. Г. Дневник 1867 года. - М.: Наука, 1993. C. $392-422$.

18. Житомирская С. В. Просто жизнь. - М.: Российская политическая энциклопедия, 2008. - 616 с.

19. Житомирская С. В. Расшифрованный дневник А. Г. Достоевской // Литературное наследство: Ф. М. Достоевский. Новые материалы и исследования. М.: Наука, 1973. - Т. 86. - С. 155-166.

20. Зализняк А. Дневник: к определению жанра // НЛО. - 2010. - № 106 [Электронный ресурc]. - URL: http://magazines.russ.ru/nlo/2010/106/za14.html (24.04.2011).

21. Измайлов А. А. У А. Г. Достоевской // Ф. М. Достоевский в забытых и неизвестных воспоминаниях современников. - СПб.: Андреев и сыновья, 1993. C. $189-195$.

22. Кобрин К. Похвала дневнику // НЛО. - 2003. - № 61. - С. 288-295.

23. Косенко П. П. Жизнь для жизни: Хроника нескольких лет Ф. М. Достоевского. - Алма-Ата: Жазушы, 1986. - 238 с.

24. Кулакова И. И. Мемуарно-автобиографическая проза А. В. Никитенко. Белгород: Политерра, 2005. - 234 с. 
25. Михеев М. Ю. Дневник в России XIX-XX веков - эго текст, или предтекст. M., 2006 [Электронный ресурc]. — URL: http://uni-persona.srcc.msu.su/site/research/miheev/kniga.htm (18.08.2011).

26. Михеев М. Ю. Фактографическая проза, или пред-текст: Дневники, записные книжки, «обыденная литература» // Человек. 2004. № 2-3 [Электронный реcypc]. — URL: http://vivovoco.rsl.ru/VV/PAPERS/MEN/PROZA.HTM (29.08.2011).

27. Ольхин П. М. Руководство к русской стенографии, по началам Габельсбергера, публично преподаваемой по поручению Министерства народного просвещения. - СПб.: тип. д-ра М. Хана, 1866. - 183 с.

28. Оскоцкий В. Д. Дневник как правда // Вопросы литературы. - 1993. - № 5. C. $3-58$.

29. Ратников К. В. <Шуточные стихи и экспромты> // Достоевский: Сочинения, письма, документы: Словарь-справочник. - СПб.: Пушкинский Дом, 2008. C. $413-414$.

30. Рогов А. А., Талбонен А. Н., Варфоломеев А. Г. Автоматизированная система распознавания рукописных документов // Труды XII Всероссийской конференции «Электронные библиотеки: перспективные методы и технологии, электронные коллекции» RCDL'2010. Казань, 2010 [Электронный ресурс]. URL: http://rcdl.ru/doc/2010/469-475.pdf. (27.04.2011).

31. Розенблюм Л. М. Творческие дневники Достоевского. - М.: Наука, 1981. - 368 с.

32. Тартаковский А. Г. 1812 год и русская мемуаристика. - М.: Наука, 1980. - 312 с.

33. Тартаковский А. Г. Русская мемуаристика XVIII - первой половины XIX в.: От рукописи к книге. - М.: Наука, 1991. - 288 с.

34. Хазанов Б. Дневник сочинителя // Октябрь. 1999. № 1 [Электронный ресурс]. — URL: http://magazines.russ.ru/october/1999/1/hasanov.html (19.03.2012).

35. Эйхенбаум Б. М. С. П. Жихарев и его дневники // Жихарев С. П. Записки современника. - М.; Л.: Издательство Академии Наук СССР, 1955. - С. 638-661.

Irina Svyatoslavovna Andrianova

Ph.D in Philology, Head of Web-laboratory,

Department of Philology,

Petrozavodsk State University

(Petrozavodsk, Russian Federation)

yarysheva@yandex.ru

\section{THE CONCEPT OF GENRE SHORTHAND DIARY A. G. DOSTOEVSKAYA}

Abstract: The shorthand diary of Anna G. Dostoevskaya, the writer's wife, comprises her notes on the creative and family life of the couple in 1867-68 during their stay in Europe. Scholars of Dostoevsky have looked at the diary of his wife as a source of biographic data, with little to no attention paid to its value as a literary text. In this article, we aim to analyse Anna Dostoevskaya's shorthand diary as a piece of literature, with a special emphasis on the history of its writing and publication, as well as on the diary's genre implications, structure, spatial and temporary features, its author and the main protagonist. This diary was the first in Russia to be written by the wife of a famous author. Since the diary was never intended for print, it was written in a very frank manner. Our conclusion is that Anna Dostoevskaya was the originator of the genre of personal shorthand diary.

Keywords: 19th century Russian literature, F. Dostoevsky, A. Dostoevkaya, memoirs, personal family and household shorthand diary 


\section{References}

1. Bakhtin M. M. Zametki k neosushchestvlennomu trudu. Problema teksta. Opyt filosofskogo analiza [Notes to the Unperformed Work. The Problem of Text. Experience of Philosophical Analysis]. Voprosy literatury [The Questions of Literature], 1976, no. 10, pp. 122-151.

2. Belov S. V. Poslednyaya lyubov' F. M. Dostoyevskogo [Last Love of Fyodor Dostoyevsky]. Poslednyaya lyubov' F. M. Dostoyevskogo: A. G. Dostoyevskaya. Dnevnik 1867 goda [Last Love of Fyodor Dostoyevsky: Anna Dostoyevskaya's Diary for the Year 1867]. Saint-Petersburg, Andreev i synov'ya Publ., 1993, pp. 5-26.

3. Bel'chikov N. F. Predislovie [Preface]. Dnevnik A. G. Dostoevskoy [Anna Dostoyevskaya's Diary]. Moscow, 1823, pp. VII-XVI.

4. V'olle K., Grechanaya E. P. Dnevnik v Rossii v kontse XVIII-pervoy polovine XIX v. kak avtobiograficheskoe prostranstvo [Diary in Russia in the end of the 18th century to the first half of the 19th century as Autobiographical Space]. Izvestiya Akademii Nauk [Proceedings of the Academy of Sciences]. Moscow, 2002, vol. 4, no. 3, pp. 18-36.

5. Gapeka L. M., Lashkevich A. B. Lichnyy dnevnik kak zhanr sub-literatury: problema struktury i funktsii «diary» v kontekste mezhkul'turnoy kommunikatsii [Personal Diary as a Genre of Sub-Literature: the Problem of "Diary" Structure and Function in the Context of Intercultural Communication]. Sintez dokumental'nogo $i$ khudozhestvennogo $v$ literature $i$ iskusstve [Synthesis of Documentary and Artistic Aspects in Literature and Art]. Kazan', 2007, pp. 391-396.

6. Ginzburg L. Ya. O psikhologicheskoy proze [On Psychological Prose]. Moscow, INTRADA Publ., 1999. 414 p.

7. Dolinin A. S. Dostoevskiy i Suslova [Fyodor Dostoyevsky and Suslova]. F. M. Dostoevskiy: Stat'i i materialy [Fyodor Dostoyevsky: Articles and Materials]. Leningrad; Moscow, Mysl' Publ., 1924, pp. 153-283.

8. Donchenko N. Yu. Poetika antinomii v «Dnevnikakh» M. Prishvina. Avtoref. dis. ... kand. filol. nauk [Poetics of Antinomy in Mikhail Prishvin's "Diaries". PhD. philol. sci. diss. abstract]. Moscow, 1999. 19 p.

9. Dostoevskaya A. G. Vospominaniya [The memories]. Saint-Petersburg, Azbuka Publ., 2011. 480 p.

10. [Dostoevskaya A. G.] Dnevnik A. G. Dostoevskoy [Anna Dostoyevskaya's Diary]. Moscow, Novaya Moskva Publ., 1923. 390 p.

11. Dostoevskaya A. G. Dnevnik 1867 goda [Diary for the Year 1867]. Moscow, Nauka Publ., 1993. 452 p.

12. [Dostoevskaya L. F.] Dostoevskiy v izobrazhenii ego docheri L. Dostoevskoy [Fyodor Dostoyevsky in the Representation of His Daughter]. Moscow; Petrograd, Gosizdat Publ., 1922. 105 p.

13. Dostoevskiy F. M. Polnoe sobranie sochineniy: $v 30$ tomakh [The Complete Works: 30 Vols.]. Leningrad, Nauka Publ., 1972-1990.

14. Egorov O. G. Dnevniki russkikh pisateley XIX veka: issledovanie [Diaries of Russian Writers of the 19th Century: Study]. Moscow, Flinta; Nauka Publ., 2002. 287 p.

15. Egorov O. G. Literaturnyy dnevnik XIX veka: Istoriya i teoriya zhanra. Dis. ... filol. nauk [Russian Literary Diary of the 19th Century. History and Theory of the Genre. PhD. philol. sci. diss.]. Moscow, 2003. 360 p.

16. Egorov O. G. Russkiy literaturnyy dnevnik XIX veka. Istoriya i teoriya zhanra: issledovanie [Russian Literary Diary of the 19th Century. History and Theory of the Genre: Study]. Moscow, Flinta; Nauka Publ., 2003. 279 p.

17. Zhitomirskaya S. V. Dnevnik A. G. Dostoevskoy kak istoriko-literaturnyy istochnik [Anna Dostoyevskaya's Diary as a Historical and Literary Source]. Dostoevskaya A. G. Dnevnik 1867 goda [Anna Dostoyevskaya's Diary for the Year 1867]. Moscow, Nauka Publ., 1993, pp. 392-422.

18. Zhitomirskaya S. V. Prosto zhizn' [Simply Life]. Moscow, Russian Political Encyclopedia Publ., 2008. 616 p. 
19. Zhitomirskaya S. V. Rasshifrovannyy dnevnik A. G. Dostoevskoy [Anna Dostoyevskaya's Decrypted Diary]. Literaturnoe nasledstvo: F. M. Dostoevskiy. Novye materialy $i$ issledovaniya [Literary Heritage: Fyodor Dostoyevsky. New Materials and Research]. Moscow, Nauka Publ., 1973, vol. 86, pp. 155-166.

20. Zaliznyak A. Dnevnik: k opredeleniyu zhanra [Diary: the Definition of the Genre]. Novoe literaturnoe obozrenie [New Literary Review], 2010, no. 106. Available at: http://magazines.russ.ru/nlo/2010/106/za14.html. (accessed 24 April 2011).

21. Izmaylov A. A. U A. G. Dostoevskoy [The Visit to Anna Dostoyevskaya]. F. M. Dostoevskiy v zabytykh i neizvestnykh vospominaniyakh sovremennikov [Fyodor Dostoyevsky in the Forgotten and Unknown Memoirs of his Contemporaries]. Saint-Petersburg, Andreev i synov'ya Publ., 1993, pp. 189-195.

22. Kobrin K. Pokhvala dnevniku [Praise to the Diary]. Novoe literaturnoe obozrenie [New Literary Review], 2003, no. 61, pp. 288-295.

23. Kosenko P. P. Zhizn' dlya zhizni: Khronika neskol'kikh let F. M. Dostoevskogo [Life for a Life: the Chronicle of Several Years of Fyodor Dostoyevsky's Life]. Alma-Ata, Zhazushy Publ., 1986. 238 p.

24. Kulakova I. I. Memuarno-avtobiograficheskaya proza A. V. Nikitenko [Memoirs and Autobiographical Prose by Alexander Nikitenko]. Belgorod, Politerra Publ., 2005. 234 p.

25. Mikheev M. Yu. Dnevnikv Rossii XIX-XX vekov - ego tekst, ili predtekst [Russian Diary of the 19-20th Centuries - Ego-Text or Pre-Text]. Moscow, 2006. Available at: http://uni-persona.srcc.msu.su/site $/$ research $/$ miheev $/ \mathrm{kniga} . h t m$ (accessed 18 August 2011).

26. Mikheev M. Yu. Faktograficheskaya proza, ili pred-tekst: Dnevniki, zapisnye knizhki, «obydennaya literatura» [Factual Prose or Pre-text: Diaries, Notebooks and "Everyday Literature"]. Chelovek [The Human], 2004, no. 2-3. Available at: http://vivovoco.rsl.ru/VV/PAPERS/MEN/PROZA.HTM (accessed 29 August 2011).

27. Ol'khin P. M. Rukovodstvo $k$ russkoy stenografi, po nachalam Gabel'sbergera [Guide to the Russian Shorthand Based on the Gabelsberger Shorthand's System]. Saint-Petersburg, Dr. M. Khan Publ., 1866. 183 p.

28. Oskotskiy V. D. Dnevnik kak pravda [Diary as the Truth]. Voprosy literatury [The Questions of Literature], 1993, no. 5, pp. 3-58.

29. Ratnikov K. V. <Shutochnye stikhi i ekspromty> [Humorous Poems and Improvisations]. Dostoevskiy: Sochineniya, pis'ma, dokumenty [Dostoyevsky: Works, Letters and Documents]. Saint-Petersburg, The Pushkin House Publ., 2008, pp. 413-414.

30. Rogov A. A., Talbonen A. N., Varfolomeev A. G. Avtomatizirovannaya sistema raspoznavaniya rukopisnykh dokumentov [Automatic Recognition System for Handwritten Documents]. Trudy XII Vserossiyskoy konferentsii RCDL'2010 [Proceedings of the 12 All-Russian Scientific Conference RCDL'2010]. Kazan', 2010. Available at: http://rcdl.ru/doc/2010/469-475.pdf (accessed 27 April 2011).

31. Rozenblyum L. M. Tvorcheskie dnevniki Dostoevskogo [Fyodor Dostoyevsky's Creative Diaries]. Moscow, Nauka Publ., 1981. 368 p.

32. Tartakovskiy A. G. 1812 god i russkaya memuaristika [The Year 1812 and Russian Memoirs]. Moscow, Nauka Publ., 1980. 312 p.

33. Tartakovskiy A. G. Russkaya memuaristika XVIII - pervoy poloviny XIX v.: Ot rukopisi $k$ knige [Russian Memoirs from the 18th to mid-19th Century: From Manuscript to Book]. Moscow, Nauka Publ., 1991. 288 p.

34. Khazanov B. Dnevnik sochinitelya [Storyteller's Diary]. Oktyabr' [October], 1999, no. 1. Available at: http://magazines.russ.ru/october/1999/1/hasanov.html (accessed 19 March 2012).

35. Eykhenbaum B. M. S. P. Zhikharev i ego dnevniki [Stepan Petrovich Zhikharev and his Diaries]. Zhikharev S. P. Zapiski sovremennika ["Notes of a Contemporary" by Stepan Zhikharev]. Moscow; Leningrad, The Russian Academy of Sciences Publ., 1955, pp. 638-661. 